DOI https://doi.org/10.30525/978-9934-26-117-6-12

\title{
МІНІАТЮРА ДЛЯ СТРУННОГО ОРКЕСТРУ «ДО МАРІЇ» ГАННИ ГАВРИЛЕЦЬ: СТИЛЬОВІ ОСОБЛИВОСТІ
}

\author{
Полєтасва О. В. \\ аспірантка кафедри історії української музики \\ та музичної фольклористики \\ Національна музична академія України імені П. І. Чайковського \\ м. Київ, Украӥна
}

Творчість Ганни Гаврилець - це самобутнє явище в сучасній українській музиці, яскравий зразок сформованого індивідуального композиторського стилю. Мисткиня працює в різних жанрах. Це i симфонічна музика, і камерно-інструментальні, і камерно-вокальні та хорові твори. Найбільшого визнання композиторка здобула своєю хоровою спадщиною. Окрім світських хорів, Г. Гаврилець пише й твори духовної тематики. $С$ також великі сценічні композиції- музичносценічне дійство «Золотий камінь посіємо» ораторія «Віють вітри» та хорові концерти «Нехай воскресне Бог!», «Кроковеє колесо», «Барбівська коляда». У симфонічному доробку мисткині знаходимо як масштабні полотна («Симфонічна поема», Симфонієта для альта і струнного оркестру «А-corda», симфонія «Паралелі», Симфонія-диптих, поема «Знаки»), так і твори-мініатюри («Сanticum», «До Марії», «Хорал», «Капричіо на честь святого Миколая», «233943 Falera», «Hуmnus»).

Індивідуальний стиль композиторки свідчить про унікальність самовираження мисткині, але й він не $\epsilon$ абсолютно «герметично»закритим. Грунтовна музична освіта (від початкової до вищої), формування естетичних орієнтирів і загалом світоглядних позицій Г. Гаврилець «закорінені» у давні та сучасні українські музичні традиції і водночас «розімкнуті» у європейський простір. Аналіз географічного компоненту творчих зв'язків Ганни Гаврилець, представленого в особі ii вчителів і наставників, дає змогу визначити основні складники й простежити спадкоємні зв'язки з музично-мистецькими традиціями інших країн. Серед них: український складник представляють львівська (Василь Куфлюк, Олександр Тищенко, Володимир Флис, Еміль Кобулей, Павло Юрженко, Станіслав Людкевич, Адам Сімович, Адам Солтис) та київська (Мирослав Скорик) школи, польський Анжей Нікодимович, Януш Корчак та інші. 
Початок самостійної композиторської діяльності Ганни Олексіївни пов'язаний з роботою у сфері естрадного мистецтва. До того, як її ім'я стало відоме завдяки конкурсу-фестивалю «Червона рута» (1989), у творчому портфелі вже були вдалі зразки у цьому напрямі.

Творчому методу Ганни Гаврилець притаманна єдність автентизму та «вокальної природи» композиторського мислення. Прикладом цього слугує низка інструментальних композицій, у яких яскраво простежується вокальна інтонаційність, фактурне оформлення музичної тканини за хоровим типом. Наприклад: «Canticum», «Хорал», «Гімн», Симфонія-диптих, «До Марії» та інші.

Ще одна риса стилю композиторки - камерний характер творчості. На це вказують жанри мініатюри, склад виконавців, ідея, зміст та емоційний спектр творів. Сама Ганна Олексіївна стверджує: «За манерою висловлювання і підходу до творчості я- камерний композитор» $[1$, с. 119$]$.

П’єса для струнного оркестру «До Марії» (2003) ілюструє різні сторони індивідуального композиторського стилю Ганни Гаврилець. Склад виконавців, до якого звертається мисткиня, сприяє втіленню сокровенної, інтимної авторської думки. Однак його виконують як більші колективи (наприклад, Національний ансамбль солістів «Київська камерата», директор та художній керівник- Валерій Матюхін; Академічний камерний оркестр «Арката», м. Вінниця, художній керівник та головний диригент - Георгій Курков), так і камерні ансамблі (Струнний квартет «Cordes», квартет солістів Національного симфонічного оркестру, м. Вашингтон, Сполучені Штати Америки та інші).

Твір є одним із перших зразків роботи із жанром оркестрової мініатюри (йому передує лише «Canticum» для струнного оркестру, 1998), але вже в ньому помітний авторський почерк композиторського письма. У композиції «До Марії» втілено основний принцип жанру мініатюри «велике в малому», за визначенням Є. Назайкінського, і він «€ не лише масштабним i кількісним, а й поетичним, естетичним і художнім критерієм» [2, с. 7651]. Згідно зі словами дослідника, у мініатюрах зіставляється мистецтво і реальність, що подається у вигляді антитез. Зіставлення божественного і реально-земного показано у трактуванні основного образу твору - Марії.

Характерною рисою стилю Ганни Гаврилець $є$ рівноцінність духовної і світської творчості. Неодноразове звернення до образу Діви Марії втілюється у різних жанрах: для хору 3 оркестром - «Stabat Mater» (образ розкрито в драматичному ключі), для струнного оркестру - «До Марії» (поєднання антитези духовного і земного), для жіночого хору - «Богородице, Діво, радуйся» (іконоподібний образ втілено у 52 
світлій православній молитві). Для композиторки «Образ Діви Маріїсвоєрідний оберіг. <..> це символ жіночої краси, енергії, любові, тепла і ніжності...» [1, с. 139].

Твір було написано з нагоди ювілею аташе з культури, американки Мері Крюгер (Марія - український аналог імені). Цей факт вплинув на звернення до джазових інтонацій, якими сповнена ця мініатюра. Але поряд із таким світським відтінком помітний і урочистий, піднесений характер, що передається хоральною фактурою і нагадує хвалебну оду Богоматері, «це славослів’я як реальній Марії, так і Її образу-символу» $[1$, c. 141].

Музичній мові твору притаманна широка мелодична лінія вокального типу, яка проводиться кілька разів, але в процесі розвитку зазнає незначних змін. Вона звучить переважно у високому регістрі, що надає їй молитовно-споглядального характеру. Одне із проведень теми супроводжується звучанням риторичної фігури catabasis, що надає звучанню відтінку настороги, але розвіюється подальшим піднесеним, квазідуховним звучанням. Натомість легкий характер музики підкреслюється традиційними для джазової музики засобами: гармонічна «золота» секвенція, гармонізація одного із проведень теми септакордами, ритмічна варіантність (синкопи, особливі види ритмічного поділу). Такі риси письма притаманні творчості наставника Ганни Олексіївни - Мирославу Скорику, він також розпочинав свій шлях як естрадно-джазовий композитор, а пізніше майстерно вплітав джазові інтонації та ритми у свої твори.

Ємність і стислість композиції п’єси «До Марії» забезпечується поєднанням ознак кількох музичних форм. На передньому плані тричастинність, але завдяки елементам гармонічного, ритмічного, фактурного, жанрово-стильового варіювання простежуються й риси варіаційності, властиві інструментальній музиці, а наявність різних варіантних змін у мелодиці надає п'єсі ознак, притаманних народнопісенній творчості. Ще один елемент, який наближає звучання до квазіцерковного - пікардійський каданс, але тут він дещо умовний, тому що реальне звучання завершується не мажорним тризвуком, а нерозв'язаним кластерним співзвуччям, у складі якого виразно чуємо високий третій ступінь ладу.

Багатовекторність стилю Ганни Гаврилець характеризується єдністю протилежностей. Вона розпочинала свій творчий шлях із популярної музики, а тепер працює в галузі академічної симфонічної, хорової, камерно-інструментальної та камерно-вокальної музики. Композиторка активно використовує народнопісенні зразки та пише духовну музику на канонічні тексти. Мисткиня увібрала досвід 
попередніх творчих поколінь та своєрідно його переосмислює у власній творчості. П'єса для струнного оркестру «До Марії» наче у зменшеному масштабі ілюструє всю широту творчого амплуа композиторки, адже бачимо поєднання рис попмузики - і молитовної, реального земного образу - із божественним, «великого в малому».

\title{
Література:
}

1. Лунина А. Е. Анна Гаврилец. Аутентика: глубинная почвенность, ментальная характерность, национальная своеобычность... попытка понять «предел смысловой беспредельности»? Лунина A. E. Композитор в зеркале современности : в 2 т. Т. 1. Киев : Дух і літера, 2015. С. $85-166$.

2. Назайкинский Е. В. Поэтика музыкальной миниатюры. Musiqi dünyasi : Beynəlxalq Elmi Musiqi Jurnalı / Azərbaycan Bəstəkarlar İttifaq1 ; Üzeyir Hacıbəyli Adına Bakı Musiqi Akademiyası. Баку, 2016. № 3 (68). S. 7649-7671.

\section{DOI https://doi.org/10.30525/978-9934-26-117-6-13}

\section{ДУНАЙ В УКРАЇНСЬКІЙ НАРОДНІЙ ТА ПРОФЕСІЙНІЙ ТВОРЧОСТІ}

\author{
Руденко Л. Г. \\ кандидат мистецтвознавства, \\ стариий науковий співробітник відділу музичних фондів \\ Інститут книгознавства Національної бібліотеки України \\ імені В. І. Вернадського \\ м. Київ, Украӥна
}

Народна творчість українського народу - надзвичайне культурномистецьке явище, позаяк у ній відображено історію, побут, звичаї, устрої українців, їх зацікавлення й прагнення досягти вершин прекрасного. Народна творчість охоплює безліч атрибутів і одне з виняткових місць у цій культурній величі посідає народний пісенний фольклор.

Особливу музичну обдарованість української нації у своїх наукових i науково-популярних працях неодноразово висвітлювали видатні вітчизняні та зарубіжні дослідники, історики, релігієзнавці, літератори, музикознавці, композитори: Гійом Де-Боплан, Павло Алепський, патріарх Никон, Макарій Булгаков, Свгеній Болховітінов, Олександр 